\title{
Calcite interval in aragonite seas: Geochemical characterization of post- extinction oolites at the Triassic- Jurassic boundary and their implications.
}

INGRID URBAN AND SYLVAIN RICHOZ

Lund University

Presenting Author: ingrid.urban@geol.lu.se

The End-Triassic Mass Extinction (ETME) is one of the five major mass extinctions of the Phanerozoic. The deposition of ooids is atypically high in the direct aftermath of major extinction events, including the ETME. Ooids were intensively investigated both petrographically and sedimentologically in the past decades; but only recently their potentialities as archives for the original chemical composition of the oceans where they formed, have gained awareness. Here we present geochemical aspects for post-ETME oolites as part of a mid-NorianHettangian section from the Emirates.

These post-extinction oolites show high variability in size and development of the cortex. They range from small $(\sim 300 \mu \mathrm{m})$ and superficial coating, to bigger (up to $800 \mu \mathrm{m}$ ) and well developed.

Bulk isotopic analyses for $\delta^{13} \mathrm{C}_{\text {carb }}$ and $\delta^{18} \mathrm{O}$ were performed on different components of post ETME oolitic samples (coated grains, matrix and cement), to be compared with the general midNorian-Hettangian trend. LA-ICP-MS analyses were performed for specific major and trace elements and give insights into seawater redox conditions during ooids formation, incorporation of silicates and nutrients, the role of bacterial strain in shaping the ooids and diagenetic processes. REE and trace elements such as $\mathrm{Mn}, \mathrm{Al}, \mathrm{Ti}, \mathrm{Zn}, \mathrm{P}$ and $\mathrm{Sr}$ were critical for this evaluation. Geochemical data point out to a calcitic deposition of these ooids as odd with the general consideration that the Late Triassic to Early Jurassic was part of the Aragonite sea. This has major implication on the understanding of the carbonate saturation in the oceans just after the mass-extinction and on the interpretation of several proxies as the $\mathrm{C}$ and $\mathrm{Ca}$ isotope-system. 